\title{
Three dimensional characteristics of young-of-year pelagic fish schools in lake
}

\author{
Jean Guillard ${ }^{1, a}$, Patrice Brehmer ${ }^{2}$, Michel Colon ${ }^{1}$ and Yvon Guennégan ${ }^{3}$ \\ ${ }^{1}$ INRA - UMR CARRTEL, BP 511, 74203 Thonon-les-bains, France \\ 2 IRD, CRHMT/UR109, 1 Avenue Jean Monnet, BP 171, 34203 Sète, France \\ ${ }^{3}$ IFREMER, CRHMT, 1 Avenue Jean Monnet, BP 171, 34203 Sète, France
}

Received 2 January 2006; Accepted 26 April 2006

\begin{abstract}
Fish schools are aggregative structures encountered in all types of aquatic environments but have as yet been little studied in freshwaters except at small spatial scales. This study represents the three dimensional description of juvenile fish schools (Perca fluviatilis and Rutilus rutilus) in a lake environment using high resolution multibeam sonar system operating at a frequency of $455 \mathrm{kHz}$, composed of 60 beams of $1.5^{\circ}$ allowing a $90^{\circ}$ observation plane. The in situ diurnal schooling behaviour of young-of-the-year fish of both species is confirmed. The morphological, energetic and spatial variables of these schools are described and related to one another. The structures described are of the same order of magnitude as those described in the marine environment. The school shape is elliptical, they are shallow and they display a temporal and spatial stability over the course of a day but a highly variable morphology. The number of vacuoles, a descriptor of the internal morphology of the schools, was found to be significantly $(p<0.01)$ correlated with the volume of the school, and showed two distinct relationships, with proportions similar to the percentage occurrence of both species sampled by a pelagic trawl. The relation may be efficient for fish species discrimination by 3-D acoustics methods in this lake with two main aggregative fish species.
\end{abstract}

Key words: Shoaling behaviour / 3-D structure / Sonar / Perca fluviatilis / Rutilus rutilus / Annecy Lake

Résumé - Caractéristiques tridimensionnelles des bancs de poissons juvéniles lacustres. Les bancs de poissons sont des structures agrégatives, observés dans tous les types de milieux aquatiques; cependant, ces bancs ont été peu étudiés dans les eaux douces, exceptés à de petites échelles spatiales. Cette étude présente la description 3-D de bancs de juvéniles de perches et de gardons (Perca fluviatilis et Rutilus rutilus) dans un lac en utilisant un système de sonar multifaisceaux à haute résolution, de fréquence $455 \mathrm{kHz}$, composé de 60 transducteurs de $1,5^{\circ}$ permettant une observation sur un plan de $90^{\circ}$. Le comportement in situ diurne en bancs, des juvéniles de l'année, des deux espèces est confirmé. Les variables liées à la morphologie et à l'énergie, et variables spatiales de ces bancs sont décrites et reliées les unes aux autres. Les structures sont du même ordre de grandeur que celles décrites dans l'environnement marin. La forme des bancs est elliptique. Ces bancs peu profonds présentent, au cours d'une journée, une stabilité temporelle et spatiale mais avec une forte variabilité morphologique. Le nombre de «vacuoles »-descripteur de la morphologie interne des bancs- s'est avéré être significativement corrélé $(p<0,01)$ avec le volume des bancs, présentant deux sortes de relation, dans des proportions semblables au pourcentage d'occurrence des deux espèces échantillonnées au chalut pélagique. Cette relation pourrait permettre la discrimination des deux espèces agrégatives par une approche acoustique 3-D dans cet environnement lacustre.

\section{Introduction}

The study of fish schools in the marine environment is now rather well documented (Fréon and Misund 1999; Bertrand et al. 2006), whereas very few studies have been conducted in situ in freshwaters on these biological structures (Milne et al. 2005), despite their quantitative and qualitative importance in lake environments. Many works describe on the mechanisms and the functions of aggregative structures, mostly

\footnotetext{
a Corresponding author: guillard@thonon.inra.fr
}

based on modelling, simulation and on laboratory experiments, but in situ only at small spatial scales in freshwaters (Hoare et al. 2000; Ward et al. 2005). In Lake Annecy, as in other large Alpine lakes, the spring recruitment of Cyprinidae and Percidae can be exceptionally high in some years. This has given rise to very strong cohorts (Gillet 2001; Kahl and Radke 2006) that can increase the total pelagic fish biomass in the lake by a factor 10 in the summer (Guillard et al. 2003). These fish, in addition to their impact on the trophic network inside the lake by both top-down and bottom-up effects 


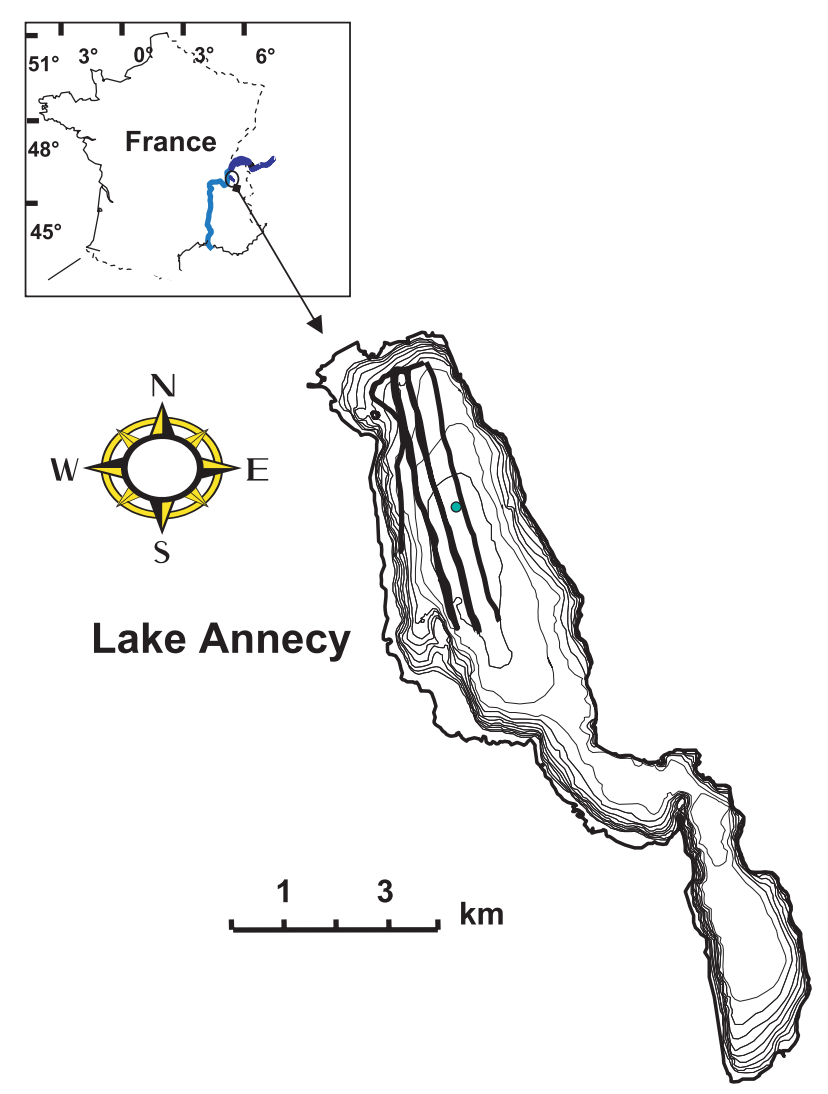

Fig. 1. Lake Annecy situated on a map of France and the transects realized during the ANSON acoustic survey (14 September 2004) shown on the Lake Annecy map. A spot indicate the localisation of the temperature profile.

(Angeli et al. 2001), can also have a considerable local economic importance (Cachera 2005). The 3-D observation of fish schools is a recent technique currently under full development which allows observation of the entire fish school (Gerlotto et al. 1999; Mayer et al. 2002). The aim of our experimentation was to describe, for the first time to our knowledge, the 3-D structures of schools of these young-of-the-year fish (Y-O-Y) using a high-resolution sonar. Working in the freshwater environment allowed us to obtain accurate acoustic measurements, with low perturbation generated by the swell (pitch and roll), of a simple fish population distributed in schools during day above the thermocline and fish scattered as individual fish targets after sunset (Guillard et al. 2004). These contexts provide a first accurate description of the in situ behaviour and intrinsic characteristics of Y-O-Y schools in fresh water, particularly focused on the "density structures" (Fréon and Misund 1999). The two species have different behaviours and physiology (Thorpe 1977; Eklöv and Persson 1995; Kahl and Radke 2006) which could lead to both kinds of school structures.

\section{Materials and methods}

\section{Field experiments}

Lake Annecy, one of the main Alpine lakes of France (Fig. 1), situated at an altitude of $446 \mathrm{~m}$, is a monomictic lake

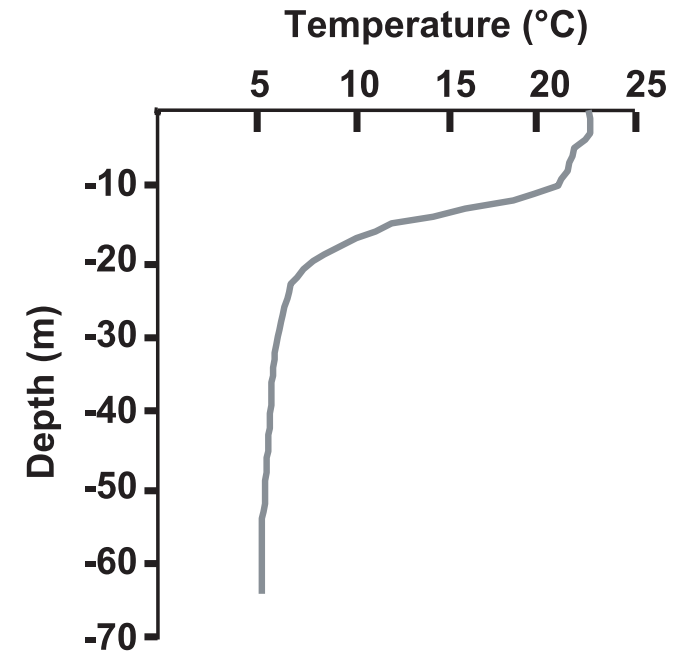

Fig. 2. Temperature profile of the Annecy Lake at the time of the acoustic survey.

of glacial origin considered to be oligo-mesotrophic (Perga 2004). It has a maximum depth of $65 \mathrm{~m}$, is $13.7 \mathrm{~km}$ long, and has a maximum width of $3.1 \mathrm{~km}$. This lake is divided into two basins and has a total area of $24.5 \mathrm{~km}^{2}$. During the experiments, from 13 to 17 September 2004, the lake was well structured with a marked thermocline between 14 and $23 \mathrm{~m}$ (Fig. 2). The thermocline caused a strong vertical partition in the distribution of fish according to the species. Above the thermocline, at the end of summer, only two main species were present in schools during daytime, roach, Rutilus rutilus and perch, Perca fluviatilis as a lot of acoustic surveys realized in this lake and other pre-alpines lakes have shown (Guillard 1991; Guillard and Gerdeaux 1993; Appenzeller 1995, 1996; Guillard et al. 2004). Schools disperse at sunset for trophic reason (Masson et al. 2001) and gather together again at sunrise. A few large salmonids also occurred in this upper layer as single echoes day and night (Guillard 1991) as described in other similar lakes (Appenzeller 1995, 1996). Fish samples were collected for target identification at night with a pelagic trawl (Guillard and Gerdeaux 1993) and the following day with a mesopelagic trawl (Meillan 2003) in the same areas where schools were detected during daytime (Table 1). No catch was obtained during daytime with the trawl, despite many trials.

\section{Acoustic methods}

A Reson Seabat 6012 multibeam sonar operated at a frequency of $455 \mathrm{kHz}$ was used for this study (Nøttestad and Axelsen 1999). The sonar was pole mounted on the side of a small boat (Antares, $6.4 \mathrm{~m}$ ) and the transducer submerged at a depth of $1 \mathrm{~m}$ during the survey (Gerlotto et al. 1999; Brehmer et al. 2005). The 60 beams (one single beam of $1.5^{\circ} \times 17^{\circ}$ ) allow a $90^{\circ}$ observation plane, oriented perpendicularly to the bottom and parallel to the surface (Fig. 3). The acoustic system parameters were TVG (Time Varied Gain) $20 \log R$, pulse length $0.06 \mathrm{~ms}$ and range $50 \mathrm{~m}$. The data storage precision was 8 bits, there is 1024 samples per beam at the used range of $50 \mathrm{~m}$ (2048 at $100 \mathrm{~m})$ and each sample 
Table 1. Catches of identification led with the pelagic trawl after acoustic observations (14 Sept. 2004). Only two species have been captured: perch and roach. The mean of each fish total length is given for the 5 trawl-samplings.

\begin{tabular}{|c|c|c|c|c|c|c|c|c|}
\hline \multirow{2}{*}{$\begin{array}{c}\text { Depth } \\
\text { of the trawl } \\
\text { (upper part) (m) }\end{array}$} & \multirow{2}{*}{$\begin{array}{l}\text { Speed } \\
\text { (knot) }\end{array}$} & \multirow{2}{*}{$\begin{array}{c}\text { Time } \\
\text { (local time) } \\
(\mathrm{GMT}+2)\end{array}$} & \multirow{2}{*}{$\begin{array}{l}\text { Duration } \\
(\min , \mathrm{s})\end{array}$} & \multicolumn{3}{|c|}{ Number of fish } & \multicolumn{2}{|c|}{ Mean length $(\mathrm{mm})$} \\
\hline & & & & Perch & Roach & Total & Perch & Roach \\
\hline 10.3 & 1.6 & $20 \mathrm{~h} 26$ & 18:06 & 41 & 0 & 41 & 60 & \\
\hline 7.8 & 1.3 & $20 \mathrm{~h} 48$ & $13: 35$ & 93 & 12 & 105 & 61 & 72 \\
\hline 6.8 & 1.4 & $21 \mathrm{~h} 05$ & $14: 13$ & 37 & 1 & 38 & 60 & \\
\hline 10.8 & 1.6 & $21 \mathrm{~h} 24$ & 13:09 & 30 & 313 & 343 & 60 & 65 \\
\hline 10.3 & 1.6 & $21 \mathrm{~h} 41$ & 13:00 & 456 & 22 & 478 & 62 & 65 \\
\hline
\end{tabular}

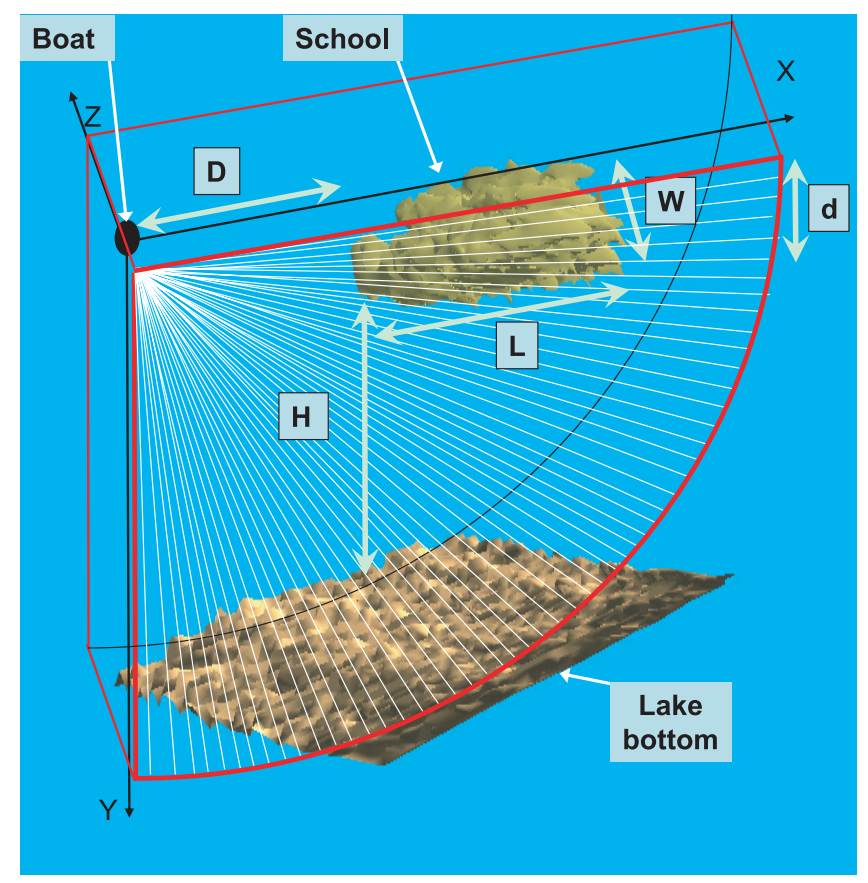

Fig. 3. Sonar view diagram of a pelagic fish school and the main parameters (Table 2) extracted from the Sbiviewer 5.01 software (the lake bottom relief below the school is also represented).

represent a distance of $4.9 \mathrm{~cm}$, which represents the definition of sonar images. A Simrad EY500 echosounder $70 \mathrm{kHz}$, with a pole mounted transducer was operated concurrently to check the bottom depth and to obtain data from the classical vertical sounding incidence. The acoustic survey, mean speed of $6 \mathrm{~km} \mathrm{~h}^{-1}$, was conducted along 6 successive transects (Fig. 1) which provided records of more than 400 sonar sequences with schools, in about 4 hours, between $11 \mathrm{~h}$ and $17 \mathrm{~h}$ local time on 14 September 2004. Using the real-time sonar display, all the fish schools detected in the sonar volume sampled were recorded. The sonar data were continuously recorded on analogue tape and converted into digital sequences via computer software (Brehmer et al. 2005). From these data, we extracted 413 fish schools and retained 388 using Sbiviewer 5.01 software digital video analysis (Lecornu et al. 1998; Gerlotto et al. 1999). Only sequences with well-identified schools, without noise and bottom interferences were retained. This process allowed us to obtain 12 descriptors (Gerlotto et al. 1999) for each fish school analysed (Table 2) (Fig. 3). The "vacuoles" were defined previously by Gerlotto and Paramo (2003) as empty

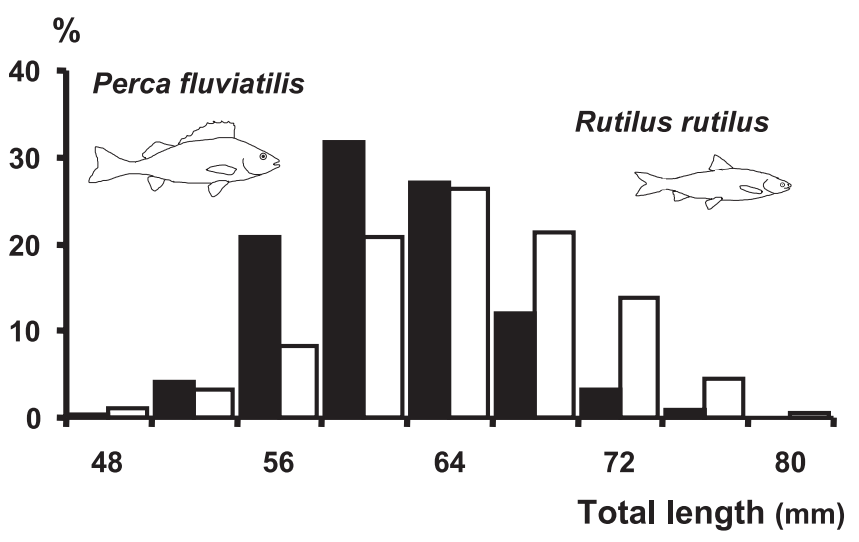

Fig. 4. Size distribution of both fish species catches: in black, perch (Rutilus rutilus), in white, roach (Perca fluviatilis).

sub-volumes in fish schools, which are known as very heterogeneous 3-D structures (Fréon and Misund 1999). The counting of the number of vacuoles detected in a school is built-in system limited to 1024 . Consecutively fish schools where the vacuole counting was equal to 1024 were eliminated, which reduced the number of schools analysed to 279 . In sonar outputs, the measurements of acoustic energy is in relative unit, obtained from the sonar system over 8-bit voltage values. The mean school relative energy is calculated using each pixel value forming the whole school (Gerlotto et al. 2001).

\section{Results}

\section{Scientific catch}

Previous experiments have shown that the percentage of each species in the trawl was dependent on the trawl locations, but that the mean length for each species was independent from location: the mean fish length is the same on the whole lake for each species (Guillard 1991). The two species have a significantly different mean length $(p<0.05)$, perch being smaller than roach (Fig. 4). More than one thousand fish were caught on 14 September in 5 trawls done in the pelagic area where data acquisition where achieved (Table 1): perch $(n=657$; $65 \%$ of the total catches; mean total length $=61.9 \mathrm{~mm}$; $\mathrm{std}=$ $4.7 \mathrm{~mm})$ and roach $(n=348 ; 35 \%$ of the total catches; mean total length $=65.5 \mathrm{~mm}$; std $=8.5 \mathrm{~mm})$. Both fish species were identified as young-of-the-year (Fig. 4). 
Table 2. Descriptive fish school variables. $D$ : distance from school edge to boat, $d$ : school edge depth, $L:$ length, $W:$ width, $H$ : height, $V:$ volume, $S$ : area, $S / V$ : roughness, $E$ : mean relative energy (256 levels), $N$ : number of vacuoles, $H S$ : vacuole area, $H V$ : vacuole volume.

\begin{tabular}{|c|c|c|c|c|c|c|c|c|c|c|c|c|}
\hline & $\bar{D}$ & $d$ & $L$ & $W$ & $H$ & $V$ & $S$ & $S / V$ & $E$ & $N$ & $H S$ & $H V$ \\
\hline & $\mathrm{m}$ & $\mathrm{m}$ & $\mathrm{m}$ & $\mathrm{m}$ & $\mathrm{m}$ & $\mathrm{m}^{3}$ & $\mathrm{~m}^{2}$ & - & - & - & $\mathrm{m}^{2}$ & $\mathrm{~m}^{3}$ \\
\hline Min. & 0.0 & 0.1 & 3.4 & 2.0 & 1.1 & 1.1 & 10.6 & 2.5 & 18.3 & 0.0 & 0.0 & 0.0 \\
\hline Mean & 12.6 & 4.9 & 17.1 & 11.7 & 8.5 & 259.8 & 2017.8 & 9.5 & 72.8 & 499.0 & 104.5 & 7.0 \\
\hline Max. & 48.0 & 18.0 & 93.3 & 46.1 & 24.3 & 5675.5 & 32831.8 & 28.0 & 211.6 & 1021.0 & 606.7 & 60.6 \\
\hline Std. & 11.4 & 3.6 & 11.6 & 6.5 & 4.5 & 521.1 & 3498.4 & 4.2 & 39.7 & 409.0 & 106.0 & 10.4 \\
\hline
\end{tabular}

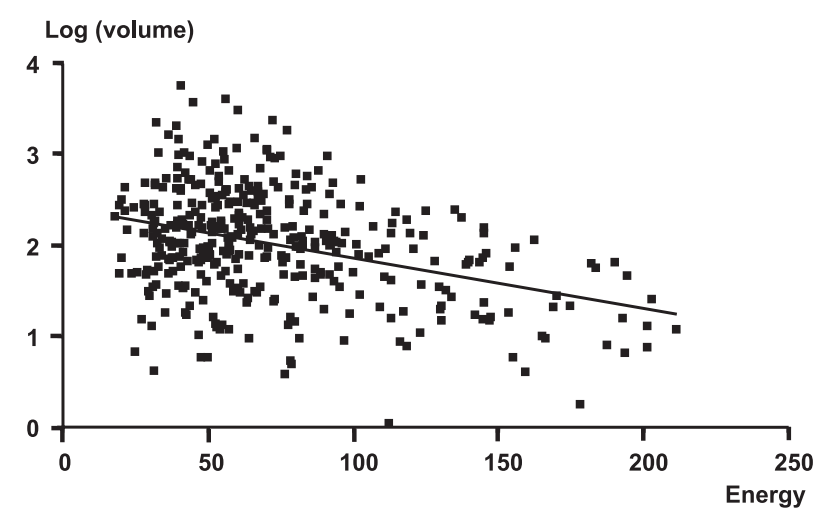

Fig. 5. Significant linear relation $(n=388, r=0.37, p<0.01)$ between volume (in Log) and mean energy of the detected schools.

\section{Morphometric characteristics}

Approximately $90 \%$ of the schools detected and digitised could be analysed (388/413). The morphological characteristics of the schools varied greatly (Table 2), reflecting the heterogeneity of the structures. The estimated volume of the schools varied from $1 \mathrm{~m}^{3}$ to more than $5600 \mathrm{~m}^{3}$ (Table 2). All measured morphological variables of the schools were significantly $(p<0.01)$ correlated $(n=388)$ : length vs. width $(r=0.82)$, length vs. height $(r=0.63)$, width vs. height ( $r=0.81)$. Length (along track) is significantly longer than width (across track) indicating a ratio width / length, for all the schools, inferior to 1 (slope of 0.74) (Milne et al. 2005).

\section{Energetic characteristics}

The mean school relative energy was also variable but no temporal trend relative to the spatial variables (distance from the boat or from the shore and depth) could be detected over the course of the day (Table 2). The mean acoustic backscatter was significantly correlated $(n=388, r=0.37, p<0.01)$ with morphological variables only, and particularly with the log-volume (Fig. 5); we observed a negative linear relation between the school mean energy and its distance to the boat.

\section{Spatial characteristics}

No significant correlations were observed between the geometric characteristics of schools and the distance from the boat ( $n=388, p<0.05$, length: $r=0.01$; height: $r=0.03$; width: $r=0.04$; volume: $r=0.02$ and area: $r=0.03$ ). Similarly, the

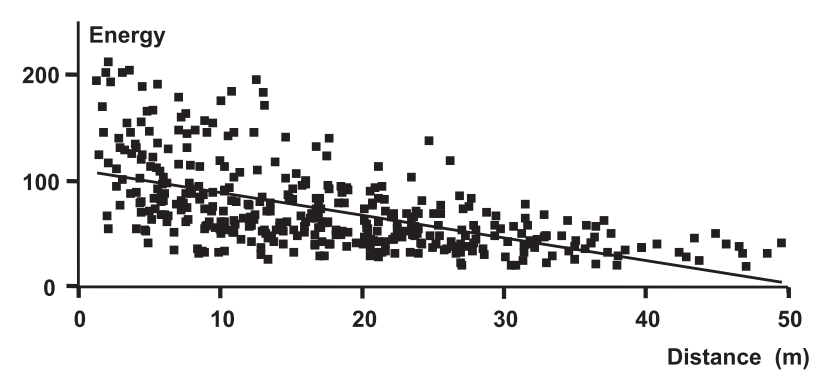

Fig. 6. Significant linear relation between distance of school from boat and energy.

number of vacuoles was not significantly correlated with the distance ( $n=279, p<0.05, r=0.06)$. However, the mean energy of each school was significantly correlated (negatively) with the distance $(n=388, r=0.56, p<0.01)$ (Fig. 6).

\section{Vacuole characteristics}

As described and defined by Gerlotto and Paramo (2003) fish schools were not composed of a compact and uniform mass: they had many vacuoles and these vacuoles varied in a major way from one school to another (Table 2). The number of vacuoles in a school was significantly correlated with the mean energy ( $n=279, p<0.01, r=0.17$ ) but not with spatial variable (distance, $n=279, p<0.05, r=0.06$ ) or temporal variable (time, $n=279, p<0.05, r=0.06$ ). Furthermore the number of vacuoles in a school was significantly correlated $(n=279, r=0.44, p<0.01, y=0.25 x+46.66$; with, $y=$ volume, $x=$ number of vacuoles) with the morphometric variables, particularly the school volume (Fig. 7). We can distinguish in this relationship two modes, even near the origin and then two distinct slopes can be identified (mode 1, $n=170,61 \%, r=0.80, y=0.76 x+37.69$; mode $2, n=109$, $39 \%, r=0.93, y=0.13 x+11.24$; with, $y=$ volume, $x=$ number of vacuoles) (Fig. 7).

\section{Discussion}

Most fish species behave gregariously at one stage or another in their development especially in the juvenile stages. So far studies of these aggregations in freshwater fish have been conducted solely on the basis of experiments, modelling or field studies but only at reduced spatial scales (Hoare and Krause 2003; Hoare et al. 2004; Tien et al. 2004; Hensor et al. 2005; Ward et al. 2005). The lesser economic importance 


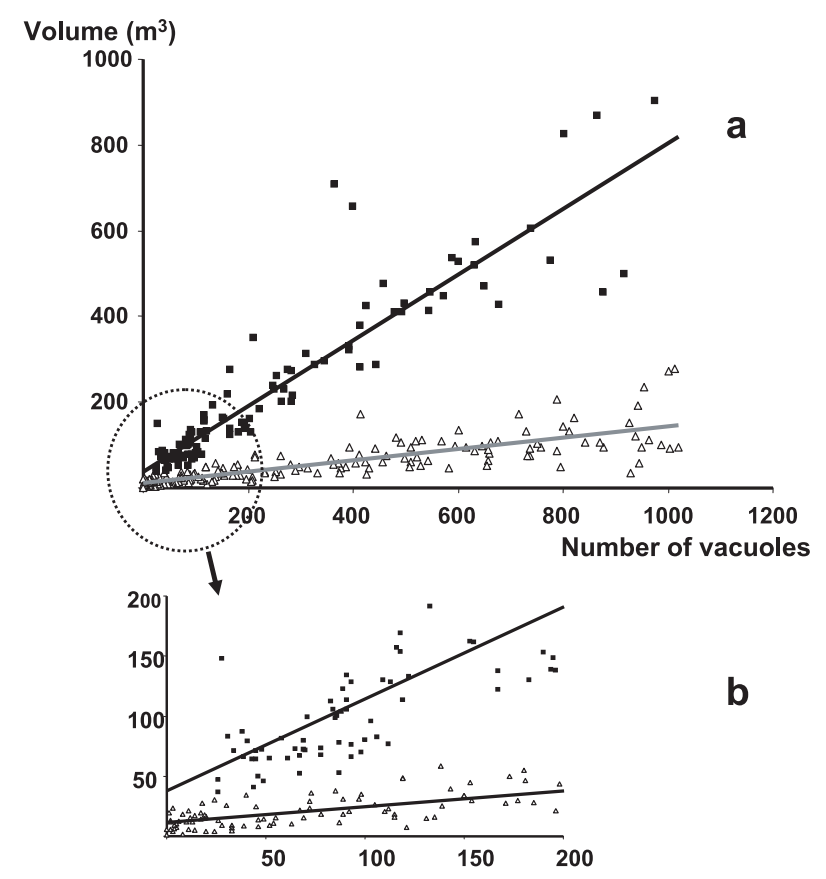

Fig. 7. (a) Significant linear relation between the number of vacuoles estimated in a school and his volume: two modes can be distinguished and then two kinds of relationships can be applied (mode 1, $n=170$, $r=0.80$; mode 2, $n=109, r=0.93$ ); (b) zoom to focus on data near the origin.

of freshwater fisheries compared to marine fisheries (Troadec et al. 2003), plus the faster technological advances in the sea, can partly explain this delay. In the marine environment, shoaling behaviour has been studied from a descriptive viewpoint (Shawn 1961; Fréon et al. 1996; Petitgas et al. 2001; Misund et al. 2003), in relation to catchability (ArreguinSanchez 1996), and from a behavioural response in relation to survey avoidance problems (Olsen et al. 1983; Brehmer et al. 2005). In our study a large number of schools was detected and recorded during a relatively short time period (less than $7 \mathrm{~h}$ ), so that we might assume the data collected be theoretically homogeneous with stable environmental conditions during this period. Furthermore the good conditions often encountered in a freshwater environment, as in our case study, enable the morphological, energetic and spatial characteristics of fish schools to be measured with great precision (Guillard et al. 2004).

The vertical spatial structure of the fish assemblage in Lake Annecy is strongly related to the thermodynamic conditions of the water layers (Appenzeller 1996). At this period of year (end of summer) the only fish occurring in schools above the thermocline were the two species (roach and perch) captured by trawls (Guillard 1991; Appenzeller 1995). The other fish present in this upper layer were isolated individuals, mainly salmonids making brief incursions from the deeper layers for foraging. In this lake fish usually disperse at nightfall and remain in the areas where they are present during the day, at least at dawn (Masson et al. 2001). The schools disperse mostly for trophic reasons (Azzali 1985; Masson et al. 2001). Sampling at night began immediately after sunset (20 h 04 official local time), as the schools dispersed (Masson et al. 2001; Milne et al. 2005), and fish could be considered as belonging to the same population detected during daytime. We made several attempts to catch schools in daytime using our trawls (Guillard and Gerdeaux 1993; Meillan 2003) which resulted all unsuccessful. This low school catchability during daytime can be related to the role of the school as an anti-predator vigilance device (Magurran et al. 1985). We were therefore unable to check the exact species composition of each school detected. The percentage of each species in individual trawls was highly variable, varying for example from $100 \%$ of perch in trawl 1 to $9 \%$ of perch in trawl 3 (Table 1). This high variability indicated that some species were more abundant in one area than in another, suggesting that monospecific schools may have occurred, as is the case for the juvenile stages of many fish species and when the two species are predator (perch) and prey (roach) (Turesson and Brönmark 2004). Previous attempts at determining the species composition using an underwater camera resulted to be unsuccessful. The percentage of each species, in the whole catch, was $65 \%$ perch and $35 \%$ roach. This result does not take into account any differences in catchability between the two species resulting from different avoidance responses (Brehmer 2004) or species dependent spatial distribution.

The schools detected had a high variability for all morphologic, energetic and spatial variables. Schools had a uniform shape: width, length and height were positively correlated. In morphological terms, there were no very tall, narrow or long schools. Schools were very shallow, as described also in the marine environment (Petitgas and Lévénez 1996; Massé et al. 1996; Muiño et al. 2003). The width / length ratio was constant and different from 1, typical of an elliptical-shaped school. As the height of schools was limited by the position of the thermocline, we found no schools taller than about twenty metres, the largest schools tending to have a flattened shape. The median measurements of the schools detected were large (median length $=14.3 \mathrm{~m}$, median width $=10.5 \mathrm{~m}$, height $7.8 \mathrm{~m}$ and area $=897.3 \mathrm{~m}^{2}$ ) and much higher than those described by Milne et al. 2005 in freshwater for the lake herring (Coregonus artedi). The morphologic parameters of our freshwater schools are similar to the values observed in seawater (Bahri and Fréon 2000; Lawson et al. 2001; Muiño et al. 2003; Gerlotto and Paramo 2003; Gerlotto et al. 2004).

It was not possible to detect any spatial and temporal change in the structures over the course of the day in terms of their morphological, energetic and spatial variables. This does not mean that the structures were fixed throughout the day, but no change could be detected: the school dynamic structures were formed at sunrise and dispersed at sunset (Fréon et al. 1996; Masson et al. 2001). Irrespective of the location, time or depth, all the schools could be detected: the school dimensions were not related to the distance to the shore or to the thermocline; the hour of the day was not influencing either: the schools were not smaller at the end of the morning than they were at the end of the afternoon. During the day, depending on various stimuli, they could change in shape, density, morphology and mean energy. The feeding behaviour of these young fish was concentrated on the periods when the zooplankton migrated into the accessible water levels and was mainly visual (Thorpe 1977; Masson et al. 2001). We may agree with the hypothesis that the diurnal formation of schools 
is unlikely related to feeding behaviour but based on their hydrodynamic and anti-predator advantages (Pitcher and Parrish 1993; Parrish et al. 2002).

The avoidance behaviour of fish when approached by boats has been studied for many years in the marine environment (Olsen et al. 1983; Fernandes et al. 2000) particularly in order to investigate its impact on stock estimates (Fréon and Misund 1999). This phenomenon has been much less studied in lakes, although some work approached these complex phenomena (Drastick and Kubecka 2005), but without being able to establish general rules or responses and only on scattered fish. The along track dimension is significantly longer than the across track, indicating a fish behavioural stimulation from the boat (Brehmer et al. 2002). In the current study it was difficult to detect changes in school morphology relative to distance to the boat, which would have reflected avoidance behaviour. The first pattern that varied in relation to the distance was the mean energy, with a lower energy as the distance increased. The fish schools are denser close to the boat, characteristics of a strong stress situation generated by predator attacks. The fact that there is a decrease in density with the boat distance could demonstrate that the avoidance reaction (characterized, here, by a decrease between each inter-individual fish distance, which produce a higher mean density of the school) continue up to the sonar range $(50 \mathrm{~m})$, otherwise the school density should stabilize around a mean. This decrease of energy with the distance could also reflect a TVG function not valid, but previous works have validated the $20 \log R$ TVG function with this kind of multibeam sonar (Gerlotto et al. 1999; Nøttestad and Axelsen 1999; Gerlotto and Paramo 2003). Our small boat might generate a horizontal avoidance reaction in freshwater fish schools, as do standard research vessels in the marine environment (Brehmer et al. 2004; Jørgensen et al. 2004). The fact that no fish were captured by trawl during daytime showed that avoidance was an important behavioural pattern in these species during our experiment, and that the fish were able to avoid the fishing device behind the boat when they were in school structure, which is characteristics of an avoidance reaction.

The mean energy of each school was extremely variable, showing a very high level of heterogeneity between schools; their density varied greatly. The densest schools, i.e. those with the highest mean energy, meaning a high fish concentration, always appeared to be the smallest; the mean energy was significantly and negatively correlated with school size. The internal school structures were not uniform but displayed many vacuoles (Fréon and Misund 1999; Gerlotto and Paramo 2003). The larger the schools, the more they became non-uniform with vacuoles. It was not however possible to demonstrate any evidence for a relation between the number of vacuoles and the mean energy in the school. On the other hand, the number of vacuoles in a school was significantly correlated with the school volume. This significant positive correlation can be separated into two distinct modes. We found no relation between the number of vacuoles and the variables recorded (distance from the boat, depth, time, geographical position or energy), that would enable us to suggest a casual hypotheses for the two types encountered. However, for a given volume there were schools with many vacuoles and others with very few.
This difference may be due to (i) schools having different behaviours, some schools dispersing as they avoid, whereas others group tightly together (Soria et al. 2003), or (ii) the presence of two distinct species, with different behaviours. If we accept the hypothesis of the existence of monospecific schools, usual for juveniles or due to the fact that schools are very often composed of individuals of the same size (Fréon and Misund 1999), proportions of each category of school (61\% and 39\%) based on the number of vacuoles are of the same order of magnitude as the species sampled by fishing during our observations ( $65 \%$ of perch and $35 \%$ of roach). We suspect that the internal morphology of schools of the two species is different, but there are insufficient data available to discern the relationship, even if previous authors (Eklöv and Persson 1995) have shown that "roach formed schools which were denser in the presence of predators, had a higher swimming speed (both in the open water and in the refuge) than juvenile perch". Further investigations are needed, especially methods for catching schools or identify schools compositions during daylight. Nevertheless, if the hypothesis is validated, this relation could be efficient tool for fish species discrimination by 3-D acoustics methods.

Acknowledgements. We are thankful to the CRHMT (IRD, IFREMER, UM II) and the UE Fadio project who provided facilities during the ANSON project. The software used "Sbiviewer 5.01" was developed during the EU project AVITIS. We also thank the referees for helpful comments.

\section{References}

Angeli N., Cretenoy L., Gerdeaux D., 2001, Importance du peuplement piscicole dans la qualité des eaux: les biomanipulations. In: Gerdeaux D. (Ed.) Gestion piscicole des grands Plans d'Eau, Paris, INRA, pp. 35-74.

Appenzeller A., 1995, Hydroacoustic measurement of spatial heterogeneity of European whitefish and perch in Lake Constance. Arch. Hydrol. Spec. Issue Adv. Limnol. 46, 261-266.

Appenzeller A., 1996, Seasonal variability patterns of acoustic estimates of fish biomass and fish size in a lake dominated by coregonids (Lake Constance). Arch. Hydrol. 50, 227-236.

Arreguin-Sanchez F., 1996, Catchability: a key parameter for fish stock assessment. Rev. Fish Biol. Fish. 6, 221-242.

Azzali M., Buracchi G., Conti S., Gambetti S., Luna M., 1985, Relationship between the forms of pelagic fish distribution and nycthemeral periods. A tentative model of behaviour. Oebalia 11, 471-488.

Bahri T., Fréon P., 2000, Spatial structure of coastal pelagic schools descriptors in the Mediterranean Sea. Fish. Res. 48, 157-166.

Bertrand A., Barbieri M.A, Gerlotto F., Leiva F., Córdova J., 2006, Determinism and plasticity of fish schooling behaviour: the example of the South Pacific jack mackerel (Trachurus murphyi). Mar. Ecol. Prog. Ser. 311,145-156.

Brehmer P., Gerlotto F., Rouault A., 2002, Inter standardization of acoustics devices: an integrated database for fish school studies. Acta Acoust. 88, 730-733.

Brehmer P., Gerlotto F., Guillard J., Sanguinède F., Guennégan Y., Buestel D., 2003, New applications of hydroacoustic methods for monitoring shallow water aquatic ecosystems: the case of mussel culture grounds. Aquat. Living. Resour. 16, 333-339. 
Brehmer P., 2004, Analyse comparée des caractéristiques dynamiques et spatiales des bancs de Sardinella aurita (Valenciennes 1847) de diverses populations : adaptations comportementales face à l'environnent et à l'exploitation; effet sur la capturabilité. Thèse Doct. Ecole Nat. Sup. Agr. Rennes, France.

Brehmer P., Gerlotto F., Anchury A., 2005, Comportamiento dinámico y reacción de evitamiento en agregaciones de peces pelágicos ante el estímulo del buque de prospección acústica. Mem. Fund. La Salle Cienc. Nat. 161, 201-214.

Brehmer P., Vercelli C., Gerlotto F., Sanguinède F., Pichot Y., Buestel Y., Guennégan Y., 2006, Multibeam sonar detection of suspended mussel culture grounds in the open sea: Direct observation methods for management purposes. Aquaculture 252, 234-241.

Cachera S., 2005, Suivi piscicole du lac du Bourget - Année 2004. CISALB Rapp. PMA03-2005, 40 p.

Drastik V., Kubecka J., 2005, Fish avoidance of acoustic survey boat in shallow waters. Fish. Res. 72, 219-228.

Eklöv P., Persson L., 1995, Species-specific antipredator capacities and prey refuges: interactions between piscivorous perch (Perca fluviatilis) and juvenile perch and roach (Rutilus rutilus). Behav. Ecol. Sociobiol. 37, 169-178.

Fernandes P.G., Brierley A.S., Simmonds E.J., Millard N.W., McPhail S.D., Armstrong F., Stevenson P., Squires M., 2000, Fish do not avoid survey vessels. Nature 404, 35-36.

Fréon P., Gerlotto F., Soria M., 1996, Diel variability of school structure with special reference to transition periods. ICES J. Mar. Sci. 53, 459-464.

Fréon P., Misund O.A., 1999, Dynamics of pelagic fish distribution and behaviour: effects on fisheries and stock assessment, Blackwell, London.

Gerlotto F., Paramo J., 2003, The three-dimensional morphology and internal structure of clupeid schools as observed using vertical scanning multibeam sonar. Aquat. Living Resour. 16, 113-122.

Gerlotto F., Castillo J., Saavedra A., Barbieri M.A., Espejo M., Cotel P., 2004, Three-dimensional structure and avoidance behaviour of anchovy and common sardine schools in central southern Chile. ICES J. Mar. Sci. 61, 1120-1126.

Gerlotto F., Soria M., Fréon P., 1999, From two dimensions to three: the use of multibeam sonar for a new approach in fisheries acoustics. Can. J. Fish. Aquat. Sci. 56, 6-12.

Gerlotto F., Hammitouch C., Simmonds E.J., Georgakarakos S., Fernandes P., 2001, Analyse et visualisation tri-dimensionelle des images sonar. Final report, Fair CT 96 1717, CRHMT, Sète.

Gillet C., 2001, Le déroulement de la fraie des principaux poissons lacustres. In: Gerdeaux D. (Ed.) Gestion piscicole des grands plans d'eau, Paris, INRA, pp. 241-282.

Guillard J., Lebourges-Dhaussy A., Brehmer P., 2004, Simultaneous Sv and TS measurements on Young-of-the-Year (YOY) freshwater fish using three frequencies. ICES J. Mar. Sci. 61, 267-273.

Guillard J., 1991, Etude des stocks pisciaires lacustres par échointégration : problèmes méthodologiques. Th. Doct. Sci. Univ. Cl. Bernard, Lyon I.

Guillard J., Angeli N., Borel C., Colon M., 2003, Dynamique saisonnière d'une cohorte de $0+$ de perche (Perca fluviatilis) suivie par hydroacoustique dans le lac d'Annecy. CILEF 2003, Montréal, 28-31 July 2003.

Guillard J., Gerdeaux D., 1993, In situ determination of the target strength of roach (Rutilus rutilus) in lake Bourget with a single beam sounder. Aquat. Living Resour. 6, 285-289.
Hensor E., Couzin I.D., James R., Krause J., 2005, Modelling densitydependent fish shoal distributions in the laboratory and field. Oikos 110, 344-352.

Hoare D.J., Couzin I.D., Godin J.G.J., Krause J., 2004, Contextdependent group size choice in fish. Anim. Behav. 67, 155-164.

Hoare D.J., Krause J., Peuhkuri N., Godin J.G.J., 2000, Body size and shoaling in fish. J. Fish Biol. 57 1351-1366.

Hoare D.J., Krause J., 2003, Social organisation, shoal structure and information transfer. Fish Fish. 4, 269-279.

Jørgensen R., Handegard N.O., Gjøsæter H., Slotte A., 2004, Possible vessel avoidance behaviour of capelin in a feeding area and on a spawning ground. Fish. Res. 69, 251-261.

Kahl U., Radke R.J. 2006. Habitat and food resource use of perch and roach in a deep mesotrophic reservoir: enough space to avoid competition? Ecol. Freshw. Fishes 15, 48-56

Lawson G.L., Barange M., Fréon P., 2001, Species identification of pelagic fish schools on the South African continental shelf using acoustic descriptors and ancillary information. ICES J. Mar. Sci. 58, 275-287.

Mackinson S., Freemanb S., Flatta R., Meadows B., 2004, Improved acoustic surveys that save time and money integrating fisheries and ground-discrimination acoustic technologies. J. Exp. Mar. Biol. Ecol. 129-140.

Magurran A.E., Oulton W.J., Pitcher T.J., 1985, Vigilant behaviour and shoal size in minnows. Z. Tierpsychol. 67, 167-178.

Massé J., Koutsikopoulos C., Patty W., 1996, The structure and spatial distribution of pelagic fish schools in multispecies clusters: an acoustic study. ICES J. Mar. Sci. 53, 155-160.

Masson S., Angeli N., Guillard J., Pinel-Alloul B., 2001, Diel vertical and horizontal distribution of crustacean zooplankton and YOY fish in a sub alpine lake: an approach base on high frequency sampling. J. Plankton Res. 23, 1041-1060.

Mayer L., Li Y., Melvin G., 2002, 3D visualization for pelagic fisheries research and assessment. ICES J. Mar. Sci. 59, 216-225.

Meillan M., 2003, Construction d'un chalut mésopélagique. Doc. Tech. TMSI pf006302, IFREMER, Brest.

Milne S.W., Shute B.J., Sprules W.G., 2005, The schooling and foraging ecology of lake herring (Coregonus artedi) in Lake Opeongo, Ontario. Can. J. Fish. Aquat. Sci. 62, 1210-1218.

Misund O.A., Coetzee J.C., Fréon P., Gardener M., Olsen K., Svellingen I., Hampton I., 2003, Schooling behaviour of sardine Sardinops sagax in False bay, South Africa. Afr. J. Mar. Sci. 25, 185-193.

Muiño R., Carrera P., Petitgas P., Beare D.J., Georgakarakos S., Haralambous J., Iglesias M., Liorzou B., Massé J., Reid D.G., 2003, Consistency in the correlation of school parameters across years and stocks. ICES J. Mar. Sci. 60, 164-175.

Nøttestad L., Axelsen E., 1999, Herring schooling manoeuvres in response to killer whale attacks. Can. J. Zool. 77, 1540-1546.

Olsen K., Angell J., Pettersen F., Lovik A., 1983, Observed fish reactions to a surveying vessel with special reference to herring, cod, capelin and polar cod. FAO Fish. Rep. 300, 131-138.

Parrish J., Viscido S., Nbaum D., 2002, Self-organized fish schools: an examination of emergent properties. Biol. Bull. 202, 296-305.

Perga M., 2004, Origines et flux de carbone dans les réseaux trophiques lacustres : étude par analyse de la composition en isotopes stables du carbone et de l'azote du zooplancton et des poissons. Th. Doct. Univ. Savoie.

Petitgas P., Levenez J.J., 1996, Spatial organization of pelagic fish: echogram structure, spatio-temporal condition, and biomass in Senegalese waters. ICES J. Mar. Sci. 53, 147-153. 
Petitgas P., Reid D., Carrera P., Iglesias M., Georgakarakos G., Liorzou B., Massé J., 2001, On the relation between schools, clusters of schools, and abundance in pelagic fish stocks. ICES J. Mar. Sci. 58, 1150-1160.

Pitcher T.J., Parrish J.K., 1993, Function of shoaling behavior in teleosts. In: Pitcher T.J. (Ed.) Behaviour of Teleost Fishes, Chapman \& Hall, London, pp. 363-439.

Shaw E., 1961, The development of schooling behaviour in fishes. Physiol. Zool. 34, 263-272.

Soria M., Bahri T., Gerlotto F., 2003, Effect of external factors (environment and survey vessel) on fish school characteristics observed by echosounder and multibeam sonar in the Mediterranean Sea. Aquat. Living Resour. 16, 145-157

Thorpe J.E., 1977, Morphology, physiology, behavior and ecology of Perca fluviatilis L. and P. flavescens Mitchell. J. Fish. Res. Board Can. 34, 1504-1514.
Tien J.H., Levin S.A., Rubenstein D.I., 2004, Dynamics of fish shoals: identifying key decision rules. Trends Evol. Ecol. Res. 6, 555-565.

Troadec J.P., Boncœur J., Boucher J., 2003, Exploitation et surexploitation des ressources marines vivantes. Académies des sciences, Rapp. Science Technol. 17, Tec \& Doc., Paris, pp. 16-56.

Turesson H., Brönmark C., 2004, Foraging behaviour and capture success in perch, pikeperch and pike and the effects of prey density. J. Fish Biol. 65, 363-375.

Vabø R., Olsen K., Huse I., 2002, The effect of vessel avoidance of wintering Norwegian spring spawning herring. Fish. Res. 58, 5977.

Ward A.J.W., Duff A.J., Krause J., Barber I., 2005, Shoaling behaviour of sticklebacks infected with the microsporidian parasite, Glugea anomala. Environ. Biol. Fish 72, 155-160. 